\title{
The Rejection of Authoritarian Policy Legacies: Family Policy in Spain (1975-1995)
}

\author{
CELIA VALIENTE
}

In contrast to other European Union member states, very few resources are dedicated in post-authoritarian Spain to family policy. This article explains this weakness of family measures in terms of the reaction of post-Francoist policy-makers against Francoist family programmes, which were pro-natalist and antifeminist, and occupied an important position in the propaganda and rituals of the regime. The article concludes that while postauthoritarian policies tend to be a continuation of preceding policies, this is not always so. An examination of the conditions under which discontinuities in public policy before and after authoritarian rule tend to appear is also undertaken.

Spain differs from other European Union (EU) member states in that its central government devotes only a small amount of its resources to family policy' (Table 1), an area of policy characterized by institutional invisibility, for Spain does not have a designated ministry or department for family affairs. The weakness of family policy in Spain cannot be explained in terms of fertility patterns. Fertility rates are in fact among the lowest in the world (Table 2). The decline in fertility has been an incentive for policy-makers in some countries to establish family policies with pro-natalist objectives, but not in Spain in recent years.

This article attempts to explain the quasi-absence of family policy in terms of the rejection of the family measures established during Franco's

I am grateful to Juan J. Limz, Isabel Madruga, Ana Rico and Juan C. Rodriguez for their valuable comments on earlier versions. They were presented at: the First Spanish Congress of Political Science, Bilbao (Spain), 5-7 Dec. 1994; the congress on Comparative Research on Welfare State Reforms of the International Sociological Association (Research Committce 19: Poverty; Social Welfare and Social Policy), Pavia (Italy), 14-17 Sept. 1995; and the Euroconference on Social Policy in an Environment of Insecurity of the European Association for the Advancement of Social Sciences and the Interdisciplinary Center for Comparative Research in the Social Sciences, Lisbon (Portugal), 8-11 Nov. 1995. An carlier version was published in Valiente (1995a). 
regime (1936-75) by post-authoritarian policy-makers. Francoist family policies were both pro-natalist and anti-feminist. One of their chief aims was to increase population, and one of the most important means they used was to try to confine women to the home, and move them away from the labour market. The salience of family programmes in Francoist official discourse and propaganda was such that they were remembered by political and social actors long after 1975 . They have since then associated any family policy with the symbols displayed and the measures enacted during Franco's regime, and have thus avoided policy-making in the area of the family.

The rejection of the legacies of the authoritarian past did not imply the immediate dismantling of most Francoist policies. This was due in part to the consensual style of policy-making during and after the transition, which implied that measures were enacted only after agreements had been reached among the most important social and political forces. Any political initiative strictly directed against the supporters of the previous regime was excluded. Francoist family programmes were not rescinded, and in general the level of benefits was not updated. As a result, the real value of the latter became mainly symbolic by the mid-1980s due to high inflation.

The first section of this article presents the theoretical basis for the explanatory argument which follows, and identifies circumstances under which post-authoritarian policy-makers tend to reject public policies made by former authoritarian governmental elites. The second section tests these theoretical insights in the empirical case of family policy in Spain after 1975.

SYNTHETIC INDEX OF FERTIUTY, SPAIN (1935-1992)

\begin{tabular}{ll}
1935 & 3.22 \\
1940 & 2.98 \\
1945 & 2.85 \\
1950 & 2.46 \\
1955 & 2.50 \\
1960 & 2.76 \\
1965 & 2.96 \\
1970 & 2.90 \\
1975 & 2.78 \\
1980 & 2.21 \\
1985 & 1.64 \\
1990 & 1.33 \\
1992 & 1.23 \\
\hline
\end{tabular}

Sources: Data for 1935-65 from Nash 1991: 164: data for 1970-92 from Instituto de la Mujer 1994: 12 
democracy), as in Spain. She affirms that political experiences under a dictatorship might make policy actors reject some practices especially associated with authoritarianism. Accordingly, she defines the concept of 'political learning' as 'the process through which people modify their political beliefs and tactics as a result of severe crises, frustrations, and dramatic changes in environment'. She also suggests that 'the process of "discrediting" old beliefs is what political learning is all about' (Bermeo 1992: 274; 281). Nancy Bermeo's insights can be developed further by trying to answer the question formulated by Peter Hall (1989: 362) in the following terms: it is all very well to say that policy makers are influenced by the lessons drawn from past policy experience, but the lessons that history provides us with are always ambiguous. Why are some lessons learned from a given policy experience, rather than others?'

Contrary to the arguments made by Hugh Heclo, Margaret Weir and Theda Skocpol (for cases of policy-making in periods where the political regime has not changed radically in a short time), policy legacies do not always favour the maintenance of past policies when a transformation in the political regime occurs. Post-authoritarian policy-makers tend to reject the policies of the former regime under six conditions.

1. When the policy had its origin in the authoritarian regime. Especially when the policy was long-lived, it is no accident that postauthoritarian political elites associate any programme in the policy area with the measures implemented in the past.

2. When the policy occupied a significant position in the rituals and ceremonies of the authoritarian regime. As a result, the policy remains very vivid in the memories of future policy actors. Sometimes, they reject former measures in an effort to present themselves to the population as 'truly' non-authoritarian elites. In this sense, the importance of the former policy in official discourse and propaganda might be a more influential factor for the future democratic policy than other more substantive aspects, such as the amount of resources devoted to financing it.

3. When the policy was implemented by a bureaucracy specially trained to deal with it and which worked in departments dedicated exclusively to it. These specialists may try to defend their position within the state during the transition period by opposing their own transfer to other departments and the dismantling of the departments where they had worked.

4. When the policy could be perceived as contrary to the fundamental rights of groups of citizens wishing to be incorporated in equal terms in the new political system (for instance, women).
5. When powerful associations that have a strong interest in maintaining and even expanding the measures already in place do not exist.

6. When the process of transition to democracy is based on the achievement of consensus among the most important political and social actors. It is then likely that policy-making will be avoided in areas which can be easily identified as having been preferred by policy actors of the authoritarian regime (under which some of the future political and social forces were illegal and repressed).

\section{CASE STUDY. FAMILY POLICY IN POST-AUTHORITARIAN SPAIN (1975-1995)}

In this section these theoretical propositions are tested in the empirical case of family policy in post-authoritarian Spain. I present both a description of family policies before and after Franco's death and examine the position and political behaviour of family organizations, feminists. state feminists, ${ }^{2}$ political parties and employers' and trade union confederations in relation to family matters after 1975.

Family Policy in Franco Spain

Family programmes were established and developed in Spain during Franco's rule and not before. Family policy occupied a prominent place in the propaganda and official discourse of the authoritarian regime. Family measures were managed by a bureaucracy not dedicated exclusively to the family but to social provision in general and/or to other matters. Due to the anti-feminist character of some programmes, family policy could be seen both then and later as inimical to women's demands for equality.

Family allowances (subsidio familiar) were first instituted in 1938 and atfected most employed people and civil servants. There were no wage restrictions in this programme. It was financed by the state, employers and workers. The amount of the allowance was the same for all families (except large ones, as explained below) and varied according to the number of children.

Family bonuses (plus de cargas familiares) were established in 1945. They were a supplementary wage (included in the paid-check) paid to most employed people, in a country where salaries were low. A percentage of the total wages paid in a company (ranging from 5 to 25 per cent in many cases) was distributed among workers according to their number of children. If beneficiaries supported a dependent spouse, they received a higher benefit. Employers financed almost entirely family bonuses. In general, they were indexed and were compatible with family allowances.

In 1954 , the existing family programmes were substituted for most 
civil servants by another type of family allowances (ayuda familiar): monthly payments for dependent children and for a dependent spouse,' Family allowances, family bonuses and ayuda familiar were normally paid to the 'head of the family', that is, to the bread-winning father, and only in very exceptional circumstances to the mother. If both parents worked, only one (usually the father) received the benefits.

Married couples were rewarded from 1941 with preferential loans whose repayment was reduced with the birth of their children. The amount of the loan was doubled if the working woman committed herself to give up her job after marriage and become a homemaker as long as her husband did not become unemployed or disabled and, therefore, unable to work. In 1948 these preferential loans were converted into one-off payments for marriage. Also from 1941, annual prizes at the provincial and national level were awarded to Spanish families with the largest number of children.

A few programmes which targeted some especially large families (familias numerosas) were established in Spain in 1926. Nevertheless, it was during Franco's rule that the most important of these measures were developed. In 1943 large families were defined as those supporting four or more dependent children. The policies consisted chiefly of higher family allowances and of preferential treatment on tax, public transportation, loans, public housing, school fees and admissions, employment of the 'head of the family', allocation of family farms and holidays in public summer camps, public vacation boarding houses and spas (Subsecretaría de Planificación de la Presidencia del Gobierno 1977: 318-20).

In 1966, family allowances and family bonuses were replaced for most beneficiaries by contributory benefits. The beneficiaries were contributors to the social security system, that is, mainly employed people. The most important benefits of this kind were monthly payments of 200 pesetas for each dependent child and 300 pesetas for a dependent spouse, and of 5,000 pesetas as one-off payments for marriage and of 2,500 pesetas at the birth of each child (Coll and Martin 1989: 70). As was the case for family allowances, the level of benefits was the same for all families (except large ones), irrespective of their income-level. Again, benefits were usually paid to the male bread-winner and very rarely to the mother. If both spouses worked, only one (usually the father) received them, with the exception of the one-off payment for marriage, which was received by both. In 1968 benefits for civil servants (ayuda familiar) were unified into monthly payments for each dependent child younger than 10 years (200 pesetas), and older than 10 years (300 pesetas), and for a dependent spouse ( 300 pesetas)
As for tax exemptions, they existed for several taxes (for instance, the Impuesto sobre los Rendimientos del Trabajo Personal and the Impuesto General sobre la Renta de las Personas Físicas). Taxes were reduced for those with dependent children and/or a dependent spouse. Some tax reliefs were directed towards large families. Several tax exemptions increased with the level of the tax payer's income (Subsecretaria de Planificación de la Presidencia del Gobierno 1977: 323-5).

At least until the mid-1950s or early 1960 s, the economic importance of family programmes was considerable, because they constituted an additional income for many employed people. Moreover, expenditure on family measures was the highest category of social expenditure in the embryonic Spanish welfare state of the 1940s. Nevertheless, in the late 1960 s and early 1970 s the level of most programmes in monetary terms was seldom updated (for instance, contributory benefits were updated only once, in 1971, between their creation in 1966 and 1975, and ayuda familiar was updated twice, in 1968 and 1975, between 1954 and 1975). Thus, due to the impact of inflation, the real value of these benefits had already begun to decline before the transition to democracy (Meil 1995: 63-72; 80, Velarde 1990: 164-7)

Family measures were not managed by a specialized bureaucracy dedicated exclusively to the family, but by an array of uncoordinated state departments which were also in charge of many other issues. Numerous family benefits were administered by the National Institute of Insurance (Instituto Nacional de Previsión, INP). It was created in 1908, before the first important family measures were established. The INP was not dedicated exclusively to family policy, but was 'the main institution for social provision' (Guillén 1992: 121). Due to the already mentioned weak development of the Spanish welfare state in the $1940 \mathrm{~s}$, the management of family programmes was one of the most important of the INP's tasks. Nevertheless, this situation changed later on, when new social policies were instituted. Subsequently, the administration of family measures became one among many of the INP's concerns. Family bonuses were managed independently in each company by a committee formed by the employer and some workers. Ayuda familiar was handled by a committee of civil servants in each department. Other family benefits were administered by other state offices, among them, the Treasury, the Home Office and the Ministries of Housing and of Education (Subsecretaría de Planificación de la Presidencia del Gobierno 1977: $315-16 ; 328$ )

Pro-natalism was one of the main objectives of Francoist family policies. They aimed to stimulate population growth by promoting a very specific type of family: that instituted by Catholic marriage, and 
composed of as many (legitimate) children as possible. Consequently, marriage was encouraged in different ways, for instance, through nuptiality loans and one-off payments for marriage. Besides, most benefits related to children were targeted until the early 1970 s only on those who were legitimate. In addition, large families were rewarded with extra-benefits and the most prolific ones with prizes.

The ideal family was a hierarchical unit, since it was assumed that authority within it rested with the father, who was supposed to be its sole (or, at worst, its main) supporter. Hence, some features of the policy reinforced the father's highly-ranking position within the family: for example, the majority of the benefits were generally paid to him and hardly ever to the mother (Nash 1991: 172-3).

The official conception of the model family also prescribed a homemaker mother. Motherhood was defined not only as the main family duty of women, but also as their main obligation towards state and society. The role of mothering was perceived as incompatible with others, such as that of waged workers. For this reason, some family programmes explicitly favoured one-earner families. This was the case of family bonuses, whose amount was substantially higher if the beneficiary supported a dependent spouse, or the contributory family benefit of payments for a dependent spouse. Moreover, in the first two decades of the regime, family policies were formulated in parallel with measures against married women's labour outside the home. Examples of this were the so-called marriage bars (prohibitions from working in some companies or sectors of the economy after marriage), or the requirement that married women obtain their husbands' permission before signing a labour contract and engaging in trade. But it was not only married women who faced obstacles to work force participation. Other policies were directed at all women: for instance, those preventing them from performing certain jobs, especially in the field of law (Valiente 1994: 149-84).

Family policy was not a hidden or implicit policy but a recurrent theme in the rhetoric and propaganda of the regime. Population concerns were emphatically expressed in political speeches, slogans and published works. The awarding of natalist prizes to the most prolific families was one of the most important rituals of the regime. The mass media amply covered such events, offering the public photographs and detailed information about the winning families of each year. Finally, the main purpose of girls' and women's political indoctrination conducted by the official women's organization of the single-party, the Seccion Femenina, was to persuade female Spaniards to perform their principal role within the family, society and the state: that of being prolific mothers and self-denying spouses (Gallego 1983: 161-74).

\section{Family Policy in Post-Authoritarian Spain}

In post-authoritarian Spain the area of the family has been characterized by an avoidance of policy-making. Most programmes inherited from Franco's time remained largely unreformed until 1985 . Their benefit levels were not updated; therefore, due to the impact of inflation, their economic importance became almost irrelevant. At that time some of them (mainly, although not exclusively, those which were more markedly anti-feminist) were abolished, while others remained extant. In the 1990 s, the remaining programmes were converted into instruments against poverty through the establishment of means tests.

Contributory benefits were not updated in monetary terms between 1971 and 1985 . Therefore, their real value had become almost symbolic by the mid-1980s. ${ }^{*}$ In 1985 , the most openly anti-feminist of these contributory benefits - that paid monthly for a dependent spouse - was abolished. The argument was that the state should not promote the status of housewives who did not work outside the house or discourage female waged work in any other way. The one-off payments for marriage and at the birth of each child were also terminated. As a result, the main contributory family benefit for employed people became the monthly payments for dependent children (250 pesetas). It is important to note that in 1986, the level of payments for dependent children was lower in Spain than in any other EU member state. Moreover, elsewhere in the EU, other family allowances existed (and continue to exist), for instance, for single parents, or at childbirth, which are still not available in Spain (Coll and Martín 1989: 72).

A modification of some family benefits took place in 1990. A means test was introduced for the contributory benefit payment for each dependent child, the amount of which was raised to 36,000 pesetas per year. In addition, a non-contributory means-tested child allowance of 36,000 pesetas was established within the social security system. ${ }^{5}$ In 1992, family benefits were abolished for most civil servants, who henceforth became eligible for the aforementioned contributory meanstested payments for dependent children. The purpose of these $1990 \mathrm{~s}$ reforms was to convert child allowances (formerly used to promote families) into measures against poverty (Meil 1994: 975-6).

But benefits for large families remained largely unreformed. Since 1975, their economic importance has decreased for two reasons: fewer and fewer families of this type exist in Spain; and inflation has taken its toll.

As for tax reliefs, the regressive Francoist tax system was replaced by the creation of a new (and progressive) income tax, the Impuesto sobre la Renta de las Personas Fisicas (IRPF). Under the IRPF system, families 
could be the beneficiaries of tax reliefs on the following three grounds: if the couple was married (until 1987); for each dependent child; and for child care expenses in certain circumstances (since 1992). ${ }^{6}$

In the area of tax law, as much as in the case of contributory family benefits, those measures perceived as anti-feminist were the most contested. After 1978, joint taxation was mandatory (husbands and wives had to pay personal income tax together) until the Constitutional Court declared it unconstitutional in 1989. The main reason for this judgement was that joint taxation penalizes families with more than one wage earner, because the salary of the second wage earner, generally the wife, may increase family revenue so as to bring it into a higher tax bracket. Since 1989, married couples have been able to choose either joint or individual taxation (each member of the family pays taxes in accordance with her/his income and independently of other family members' income).

The economic importance of tax relief is nowadays greater than that of current transactions. Gerardo Meil (1994: 976-9) has calculated the importance of IRPF tax deductions with regard to the programmes set out in Table 1 (as well as with other measures not considered by this article, such as subsidies paid to women during maternity leave and medical spending associated with maternity). His conclusion is that tax reductions do not fully compensate for the low level of social expenditure on family programmes in Spain (see Table 1) although they do reduce the distance between Spain and other countries a little.

In sum, family measures in Spain at the end of 1990s were: tax relief for IRPF tax payers administered by the Treasury; non-contributory and contributory child allowances for those with low or no income, managed by the National Institute of Social Security (Instituto Nacional de la Seguridad Social), which is dependent on the Ministry of Labour and Social Security; and benefits for large families, handled by a range of state departments. In comparative terms, family policy is characterized by a very low level of spending and by institutional invisibility.

\section{SOCIAL AND POLITICAL ACTORS IN AREAS OF FAMILY POLICY POST-1975}

Most political and social actors have refrained from activity in the area of family policy in Spain after 1975, and this can be explained by their rejection of the authoritarian past. In the following I examine the position of these actors in relation to family issues and also their actual behaviour at certain critical moments.

Family Organizations

In countries like France or Belgium, family organizations matter in policy-making because of their large membership and political and social influence. In the Netherlands, Belgium and France, family associations participate in consultative bodies for family policies (Dumon 1990: $363-4)$. In post-authoritarian Spain, family organizations are probably the main collective advocate of strong family policy. Nevertheless, their influence in the policy-making process is negligible, due to the low number of members, the fact that the majority of them are organized at the local or provincial level and the absence of suitable platforms at the national level (Iglesias 1994: 540-2).

\section{The Feminist Movement}

As for the feminist movement, many feminist groups were formed in Spain in the late 1960s and early 1970s, and together with other organizations and political groups they participated in the opposition to the authoritarian regime (Scanlon 1990: 94). Spanish feminists rejected the system of beliefs which had inspired Francoist policy-makers when they were establishing family policies.

Spanish feminists have made a very small contribution to feminist thinking, and have imported most of it from abroad, mainly by reading translations of foreign theoretical writings (Threlfall 1985: 59-60). In general, and with important exceptions, many international feminist theoreticians have reacted against traditional interpretations of the family as the place where most individuals (irrespective of their gender and age) find self-fulfilment. Such feminist thinkers have placed a great deal of emphasis on understanding the family as one of the main loci where women have an inferior status (Eisenstein 1991: 86-96). Activists in Spain were receptive to these theoretical approaches and, with their help, analyzed the Francoist experience, and/or confirmed their own partly formed views about it. In fact, most Spanish feminists believed that the best family policy (as defined in this article) is a non-policy. They argued that the state should not promote a social unit, the family, in which, according to their views, women, in comparison with men, are economically less powerful, perform a disproportionate (if not the total) share of domestic tasks and caring functions and are often victims of domestic violence.

\section{State Feminists}

Femocrats have existed in Spain since the mid-to-late 1970s. Nevertheless, the state feminists with whom this article is concerned are those belonging to the main feminist institution of the central state, the Institute of Women (Instituto de la Mujer, IW), which was founded in October 1983. 
It is hardly surprising that both feminists and IW femocrats agreed on the rejection of Francoist or of any other family policy (it should be noted that no IW department has responsibility for family affairs). A few IW femocrats are former activists in the feminist movement. In addition, some of the first high ranking IW femocrats and other people who participated in the establishment of the IW were members of the PSOE or were very close to it. As explained below, this party paid little or no attention to the promotion of families through public policies.

\section{Political Parties}

Heclo $(1974: 301-4)$ has argued that the role played by high-ranking bureaucrats is more important than that of politicians when crucial decisions in the area of social policy are taken. Nevertheless, the contrary argument can be made for transitions to democracy and consolidation processes, when political parties are central actors in policy-making.

(1) THE CENTRE-RICHT UCD

The centre-right Unión de Centro Democrático (UCD) was in government between 1977 and 1982 . It is reasonable to suppose that the UCD would have been interested in family matters and would have proposed the development of family policies, as was the case for numerous centre-right and conservative parties in other western countries. Surprisingly, the UCD was not an advocate of more (or more extensive) family policies. This was reflected, initially, in the low priority that such issues received initially in electoral programmes and, later, in the actual political behaviour of the UCD.

Regarding the UCD's electoral programmes, although each contained one or two statements about the family as 'the basic institution of society' (UCD 1977: 13), or 'the best sphere for the development of human beings and their basic values', and the 'school of solidarity for children' (UCD 1979: 25), little or no mention was made of concrete family policies.

As for UCD political behaviour, it was precisely during their period in office that funding for most family programmes was cut back substantially in real terms, simply because benefit levels were never adjusted in line with inflation. In addition, important opportunities for a broad and in-depth debate on the reform of family policy were missed between 1977 and 1982 when neither the UCD nor any other relevant social or political actor seemed interested in it.

One of these opportunities was provided by the discussions on the reform of the social security system held in the mid-1970s by political parties, trade unions, employers' associations, the bureaucracy and academics (Guillén 1992: 127-8). Although contributory family benefits were a part of the social security system government doctuments contributing to this debate only made a passing reference to family policy. What was normally affirmed was merely that, in general, the level of benefits was already ridiculously low, and that the most anti-feminist benefits, such as the monthly payments for dependent spouse, had to be abolished. No analysis whatsoever was made of family policy in terms of its objectives, means and results."

Another missed opportunity was the preparation of the new income tax, the IRPF, in the late 1970 s. Policy-makers tried to enlarge the economic capacity of the state by raising revenue from citizens more efficiently, and by setting up a progressive system which would redistribute income vertically (from those with more to those with less income). The purpose of redistributing income towards those with family responsibilities was not among the objectives of political-decision makers (Iglesias 1994: 527-8).

Several factors help to explain the near-absence of family policy issues in the UCD's public discourse and political behaviour. Obvious as it may seem, other matters usually take precedence in a transition to democracy and the democratic consolidation process, such as the legalization of political parties and trade unions, the writing of the Constitution or negotiations with the Army to prevent a military backlash.

In addition, the transition to democracy took place in Spain through a consensus reached among all political and social forces. In order to achieve general agreements of this kind, it was necessary for actors to concentrate on and emphasize what they have in common and can agree about. In order to do this, UCD policy-makers tried to avoid using the symbols and discourse and measures of the authoritarian regime, under which many of the political and social forces involved in the transition process were outlawed. Family programmes were precisely the kind of issues to be avoided, because of their high salience in the Francoist rhetoric.

Finally, the rejection of policy-making in the area of the family under UCD (and PSOE) governments was facilitated by the absence of a powerful bureaucracy specialized in family affairs, or organized to defend the continuation or the strengthening of such measures.

\section{(II) THE SOCIAL DEMOCRATIC PSOE}

The PSOE was the main opposition party until 1982, when it formed its first government. It has remained in power until the present day (at the time of writing it has narrowly lost a general election to the Partido Popular [Popular Party]). Family policy has been a non-priority area for the PSOE over the past two decades, as is shown by its electoral 
PSOE feminists were particularly active in their attempt to avoid any family policy. ${ }^{9}$ They argued that women had traditionally been associated with the care of children, dependent people and the family, in general Feminist socialists wanted to act politically on behalf of women alone, and not in the name of women as part of their families. ${ }^{10}$ The strategy recommended by PSOE feminists was two-fold: the establishment of gender equality policies in order to reduce the differences (for instance, in terms of education or employment) between female and male citizens; and by implication the avoidance of family policies, which (in their view) indirectly focus on the tasks performed by women in their families. This recommended course of action was important not because it was held by a minority sector within the PSOE, but because it became widespread within the whole party.

A former head of the PSOE women's secretariat, Matilde Fernández, was appointed as the first Minister of Social Affairs in 1988, when the Ministry was established. One of its aims is the development of policies directed towards groups of citizens in particularly disadvantageous circumstances, such as women, immigrants or the handicapped. Not surprisingly, this Ministry does not have an important section with responsibility for the family. Matilde Fernández clearly affirmed that social policy had to be targeted on individuals and not families, and that the latter would be recipients of benefits only in very exceptional circumstances (Fernández 1989: 96). Similar declarations have been made by Cristina Alberdi, the second Minister of Social Affairs, appointed in 1993, who was for many years a well-known feminist lawyer before she started a political career (El País 20 Dec. 1995: 28).

The PSOE has paid hardly any attention to family policy. For instance, government documents about the aforementioned discussions on social security system reform" ${ }^{\text {" }}$ only made very few references to family programmes. These references usually proposed the abolition of the most markedly anti-feminist measures and suggested targeting the rest on families with very low or no income. In fact, the eradication of the most anti-feminist programmes (1985) and the conversion of contributory benefits into instruments against poverty (1990) constituted the only two relevant exceptions to the general pattern of inaction which has characterized the PSOE's behaviour in this area.

(III) THE CONSERVATIVE PP

Since 1982, the conservative party - under the names of Alianza Popular (AP), Coalición Popular (CP) and Partido Popular (PP) - has been the

main opposition party. The relatively modest role played in family policy-making by the PP is particularly striking. Its electoral programmes have paid more attention to family policy issues than those of the UCD and the PSOE (AP 1977: 16; 34, 1982: 135-6, CD 1979: 7; 11-12; 21-2; 37-9, CP 1986: 55, PP 1989: 28-30; 60, 1993: 96-8). Some written documents and lectures by former PP president, Manuel Fraga (1977: 97-101, 1984), have stated that the family is one of the basic institutions in society, and that more active family programmes must be established in Spain.

Nevertheless, when actual PP political behaviour is examined, the importance given family issues by PP policy-makers is in fact less than its public discourse might suggest. For instance, as far as PP parliamentarian activity in the low chamber between 1977 and 1995 is concerned, its members of parliament presented few legislative proposals aimed at increasing the amount of family contributory benefits, and addressed a very low number of questions to the government on family matters. It should be emphasized that most of these parliamentary motions were made only in the 1990s, especially around 1994, which was declared International Year of the Family by the United Nations. Therefore, PP parliamentary activity has been very limited in the area of the family.

Historical memories help us understand why PP politicians have acted differently from conservative political elites in other EU member states. Since the transition to democracy, the PP has tried to present itself to the electorate as a new and truly democratic party, and not as the heir of Francoism. This was not an easy task, since some PP leaders - for instance, its former president, Manuel Fraga - had also been prominent politicians under the authoritarian regime. Therefore, PP leaders carefully avoided the use of issues and symbols represented by such issues as the family which could be easily associated with the authoritarian past.

To conclude this analysis of public discourse and behaviour of political parties, it should be stressed that no important Christiandemocratic party exists in Spain, in part because the Catholic Church did not support the formation of such a political force. In other countries, Christian Democratic parties are one of the main advocates of broad and comprehensive family policies.

Social Partners

As all other relevant policy actors, and for the same reasons, the main social partners, the employers' confederation Confederación Española de Organizaciones Empresariales (CEOE) and the trade union confederations Unión General de Trabajadores (UGT) and Comisiones Obreras (CCOO), have also avoided policy-making in the area of the 
family. First, they have not discussed family policy to any significant extent during the above-mentioned debates on the reform of the social security system, as can be read in the documents with which employers (CEOE 1981, 1982: 13, 1983, 1985, Círculo de Empresarios 1979: 14; 72-4; Jiménez 1982) and trade unions contributed to these debates. ${ }^{12}$ Second, the social pacts signed by the employers' confederation, and/or unions and/or the state, such as the Acuerdo Marco Interconfederal (1980), the National Agreement on Employment (1981), the Acuerdo Interconfederal (1983) or the Economic and Social Agreement (1984), but also the so-called 'Moncloa Pacts' signed by political parties, did not contained any reference to family policy at all. ${ }^{13}$ Third, in collective bargaining, trade union confederations have given hardly any instruction to workers' representatives to negotiate on family matters, such as payments for marriage, birth of children and support of dependent children or a spouse (Iglesias 1994: 537). Not surprisingly, the establishment of such payments is generally not considered in collective agreements (Álvarez and Márquez 1994: 201, Casas 1977, Castiñeira 1989: 1023, Del Rey and Durán 1993: 884, Gallardo 1991: 483).

\section{CONCLUSION}

This article has shown that, in comparison with other EU member states, Spain is distinguished by the low importance accorded to family policy. This specificity can be understood in terms of historical memories. After 1975 , all relevant political and social actors wanted, at any price, to be seen as distant and as opposed as possible to the pro-natalist and antifeminist Francoist family policies, which were highly proclaimed in the official discourse of the regime. Post-authoritarian political and social forces associated any family programme with the measures established in former times, and therefore avoided policy-making in this area. Due to the consensual style of politics in the transition to democracy and in the consolidation process, inherited programmes were not dismantled. They endured for a decade or longer, because of the impact of inflation and the absence of a powerful bureaucracy mobilized in their defense.

Similarities between the Spanish welfare state and other welfare states have already been emphasized (Esping-Andersen 1995, Guillén 1990, 1992). Without denying that generally speaking welfare states in western countries and in Spain are more similar than different, one main difference is certainly the low importance of family policy in the latter. This is also the case for other Southern European countries.

Although much more research on social policies in post-authoritarian countries is needed, it is reasonable to suppose that a rejection of former

public policy occurs under the six circumstances identified in this article, that is, when the policy originated in the authoritarian period; was given a high profile in the propaganda of the regime; was not administered by a specialized bureaucracy committed exclusively to it; its continuation is seen as endangering the rights of groups of citizens (for instance, women) wishing to be included in equal terms in the new political system; it is not effectively defended by any important social actor; and had to survive a process of transition to democracy of a consensual nature. These propositions could be tested either for other social policies in Spain or in other southern European states, or for family policies in Italy, Portugal and Greece, which also experienced periods of authoritarian rule, and in which family policy still has a low profile today (see Table 1).

NOTES

1. I share the detinition of family policy developed by Jane Jenson and Mariette Sineau 1994: 24) as those 'social programs involving direct or indirect expenditures on atrilies and their needs. These types of expenditures, via transfer payments and tax expenditures [are] made by the state.' This definition leaves out another aspect of family policy: 'the regulation of relations within the family, through laws on marriage, divorce, and inheritance, which establish the respective rights and duties of family members'. Three points of clarification are necessary here. First, although the targets of family policies can be families composed of one or two parents and children as well as other relatives, only programmes aimed at parents (one or two) and their dependent children are examined. Second, this article analyzes the family policies of the central government, not of regional or local governments. Third, due to limitations of space and the scinty of secondary material on family policy in Spain and the searciny of secondary mate considered here.

2. Since the 1960s. institutions with the explicit purpose of promoting gender equality dismanted) in most industrial have oeent set up, developed (and sometimes even dismantled) in most industrial

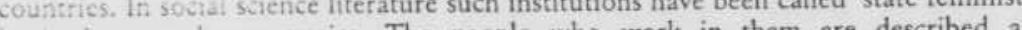
institutions or bureaucracies. The people who work in 'femocrats' or 'state feminists' (Stetson and Mazur 1995).

3. High-ranking civil servants received the following amounts for a dependent child vounger than 10 years, older than 10 years and a dependent spouse: 200,300 and 300 pesetas, respectively. Low-ranking civil servants received 160,240 and 240 pesetas.

4. In 1971 , the monthly payment for a dependent child and for a dependent spouse amounted to 6.13 per cent and 9.19 per cent, respectively, of the monthly minimum wage of 4,080 pesetas. In 1985 , these percentages were 0.62 per cent and 0.93 per cen fof the minimum wage of 40,140 pesetas) (Coll and Martin 1989: 70).

5. In Dec. 1993, 2,136,807 children were indirect beneficiaries of the contributory and non-contributosy benefit for dependent children (Instituto Nacional de la Seguridad Social 1994: $3^{-5}$.

6. The number of families for which the amount of tax to be paid was reduced because the couple was married rose every year, from $4,853,989$ in 1981 to $5,835,659$ in 1987 , the last vear of existence of this tax relief. The number of families and/or individuals the last veat o: existetse of this tax relief. Therting dependent children also increased whost almost ever: vearie 
families) were the beneficiaries of tax reliefs for child care. These data are taken from Ministerio de Economía y Hacienda (1981-1994).

7. The two main IW programmatic documents are the two Equality Plans (Instituto de la Mujer 1987, 1993). They provide the main sources for this section, together with indepth interviews carried out with femocrats for Valiente (1995b).

8. See, for instance, Presidencia del Gobierno (1982: 54-5) and 'Propuesta de medidas de racionalización y mejora de la Seguridad Social' (1982:11; 17). The above-mentioned debate on the social security reform is summarized in Velarde (1990: 291-354).

9. In 1976, a women's caucus, Mujer y Socialismo, was formed within the party. In 1981, a member of this caucus was elected to the PSOE's Executive Committee and others followed her in successive years. In December 1984, the women's caucus was raised by the party to the status of a women's secretariat at Federal Executive level (Threlfall 1985: 48-9)

10. Personal interview with Matilde Fernández, former Minister of Social Affairs 1988-93 - 13 April 1994.

11. See, for instance, Gonzalo et al. (1985), Ministerio de Trabajo y Seguridad Social (1985: 40-1, 137-8) and Secretaría General para la Seguridad Social (1991).

12. These contributions can be consulted in Papeles de Economía Española, special issue 'Social Security (Documents)' (1982). Another piece of evidence of the non-priority of family policy issues for the social partners is the absence of references to the matter in their main periodicals. I have consulted all numbers of CEOE: Boletin Informativo (Dec. 1980-Nov. 1995) and of Unión from UGT (June 1981-Nov. 1995). I have not found any article about the issue under consideration here.

13. The aforementioned pacts can be consulted in De la Villa (1985).

\section{REFERENCES}

Aivarez, J, and A. Márquez (1994): 'La Seguridad Social y los convenios colectivos', in F. Navarro (ed.), XI Jornadas universitarias andaluzas de Derecho del Trabajo y relaciones laborales, Madrid: Trotta and Consejo Andaluz de Relaciones Laborales, pp.179-206. AP (1977): Qué es Alianza Popular, Madrid: Alianza Popular.

- (1982): General Elections: Electoral Programme.

Bermeo, N. (1992): 'Democracy and the Lessons of Dictatorship', Comparative Politics, April, pp. 273-91.

Casas, M. (1977): Autonomia colectiva y Seguridad Social, Madrid: Instituto de Estudios Fiscales.

Castineira, J. (1989): 'La protección a la familia en la negociación colectiva 1987-1988', Relaciones Laborales, II, pp.1023-34.

CD (1978): General Elections: Electoral Programme.

CEOE (1981): 'Consideraciones sobre la financiación de la Seguridad Social en Espana', Informes y Estudios de CEOE 7, June-July, pp.13-17.

- (1982): 'Análisis del programa de mejora y racionalización de la Seguridad Social', Informes y Estudios de CEOE 16, May, pp.9-18.

(1983): 'La reforma de la Seguridad Social desde el punto de vista empresarial', Informes y Estudios de CEOE 26, Oct.-Nov., pp.15-36.

(1985): 'Reflexiones sobre la reforma de la Seguridad Social', Informes y Estudios de CEOE 35 , March-April, pp. 21-4.

Circulo de Empresarios (1979): Documento Base para el estudio de un modelo de Seguridad Social en España, Madrid: Círculo de Empresarios.

Coll, P. and R. Martín (1989): 'La protección de la maternidad, de la familia y de la vivienda', Revista de Economia y Sociologia del Trabajo 3, pp.67-83.

CP (1986): General Elections: Electoral Programme.

De la Villa, L. (ed.) (1985): Los grandes pactos, acuerdos y convenios colectivos a partir de la transición democrática: antologia, Madrid: Ministerio de Trabajo y Seguridad Social.
Del Rey, S. and G. Durán (1993): 'Las mejoras voluntarias: análisis de la reciente Trabajo 62, Nov.-Dec., pp.867-914

Dumon, W. (1990): 'Family Policy in the EEC Countries: A General Overview', in W Dumon (ed.), Family Policy in EEC Countries, Luxembourg: Office for Official Publications of the European Communities, pp.351-69.

Eisenstein, H. (1991): Gender Shock: Practicing Feminism on Two Continents, Sydney: Allen \& Unwin.

Esping-Andersen, G. (1995): 'Welfare States Without Work: The Impasse of Labor Shedding and Familialism in Continental European Social Policy', Centro de Estudios Avanzados en Ciencias Sociales Estudios/Working Papers 7

Fernández, M. (1989): 'Protección social y política de igualdad: Estado y sociedad', Cuadernos de Acción Social 16, pp.94-101.

Fraga, M. (1977): Alianza Popular, Bilbao: Albia.

(1984): 'La familia y la política', in Fundación Cánovas del Castillo (ed.), Jornada Nacional sobre la Familia, Madrid: Fundación Cánovas del Castillo, pp.61-7.

Gallardo, R. (1991): 'Las mejoras complementarias del sistema de la Seguridad Social en la negociación colectiva', Reiaciones laborales $7 / 23$, pp. $8-23$.

Gallego, M. (1983), Mujer, Falange y Franquismo, Madrid: Taurus.

Gonzaio, B., F. Ferreras and J. Tejerina (1985): Evolucion y tendencias de la Seguridad Soclat ditrante la crists cconomica, Madrid: Ministerio de Trabajo y Seguridad Social.

Guillen A (1990): 'The Emergence of the Spanish Welfare State (1876-1923): the Rele of Idiess in the Policy Process'. Centro de Estudios Avamados on Ciencias Sociates Estudios Working Papers 10.

- (1992): 'Social Policy in Spain: From Dictatorship to Democracy (1939-1982)', in Z Ferge and J. Kolberg (eds.), Social Policy in a Changing Europe, Frankfurt am Main and Boulder. CO: Campus Verlag and Westview Press, pp.119-42

Aall, P. (1989): 'Conclusion: the Politics of Keynesian Ideas', in P. Hall (ed.), The Political Powet of Economic Ideas: Keynesianism Across Nations, Princeton, N]: Princeton Cniversity Press, pp.361-91.

Heclo, H. (1974): Modern Politics in Britain and Sweden: From Relief to Income Maintenance, New Haven, CT: Yale University Press.

Iglesias, J. (1994): 'La política familiar durante la transición', in Fundación Foessa (ed.), V Informe soctológico sobre la situación social en España, Madrid: Fundación Foessa, pp. $525-42$.

Instituto de la Mujer (1987): First Equality Plan, 1988-1990.

- (1993): Second Equality Plan, 1993-1995.

p.12.

Instituto Nacional de la Seguridad Social (1994): Memoria 1993, Madrid: Instituto Nacional de la Seguridad Social.

enson, 1. and M. Sineau (1994): 'Family Policy and Women's Citizenship in Mitterrand's France', paper presented at the conference 'Crossing Borders: International Dialogues on Gender, Social Politics and Citizenship', Stockholm, 27-29 May.

Iiménez, J. (1982): 'Situación y reforma de la Seguridad Social', in Fundación Friedrich Fert (ed.), La reforma de la Seguridad Social, Madrid: Fundación Friedrich Ebert, pp. $193-204$.

Meil, G. (1994): 'L'évolution de la politique familiale en Espagne', Population 4-5, pp. $959-84$

- (1995): 'La política familiar española durante el franquismo', Revista Internacional de Sciologia 11, May-Aug., pp.47-87

Ministerio de Economia y Hacienda (1981-1994): Memoria de la Administración Tributaria. Madrid: Ministerio de Economía y Hacienda.

Ministerio de Trabajo y Seguridad Social (1985): Documento base sobre la reforma de la Segaridad Sarial, Madrid: Ministerio de Trabajo y Seguridad Social. 
Nash, M. (1991): 'Pronatalism and Motherhood in Franco's Spain', in G. Bock and P. Thane (eds.), Maternity and Gender Policies: Women and the Rise of the European Welfare States, 1880s-1950s, London: Routledge, pp.160-77.

Papeles de Economia Española, special issue 'Social Security (Documents)' (1982).

PP (1989; 1993): General Elections: Electoral Programmes.

Presidencia del Gobierno (1982): La Seguridad Social española: programa de mejora y racionalización, Madrid: Presidencia del Gobierno.

'Propuesta de medidas de racionalización y mejora de la Seguridad Social', Papeles de Economia Española, special issue 'Social Security (Documents)' (1982), pp.1-19.

PSOE $(1977 ; 1979 ; 1982 ; 1986 ; 1989 ; 1993)$ : General Elections: Electoral Programmes.

Scanlon, G. (1990): 'El movimiento feminista en España, 1900-1985: logros y dificultades', in J. Astelarra (ed.), Participación Politica de las Mujeres, Madrid: Centro de Investigaciones Sociológicas and Siglo XXI, pp.83-100.

Secretaria General para la Seguridad Social (1991): Estudios preparatorios para la Ley de prestaciones no contributivas, Madrid: Ministerio de Trabajo y Seguridad Social.

Sterson, D. and A. Mazur (eds.) (1995): Comparative State Feminism, Thousand Oaks, CA: Sage.

Subsecretaría de Planificación de la Presidencia del Gobierno (1977): Acción protectora y estructura orgánica de la Seguridad Social, Madrid: Subsecretaría de Planificación de la Presidencia del Gobierno.

Threlfail, M. (1985): 'The Women's Movement in Spain', New Left Review 151, pp.44-73.

UCD (1977; 1979): General Elections: Electoral Programmes.

Valiente, C. (1994): Politicas pubilicas para la mujer trabajadora en Italia y España (1900-1991), Madrid: Instituto Juan March.

- (1995a): 'Rejecting the Past: Central Government and Family Policy in PostAuthoritarian Spain (1975-94)', Cross National Research Papers 4/3, pp.80-96.

- (1995b): 'The Power of Persuasion: The Instituto de la Mujer in Spain', in D. Stetson and A. Mazur (eds.), Comparative State Feminism. Thousand Oaks, CA: Sage, pp. $221-36$.

Velarde, J. (1990): El tercer viraje de la Seguridad Social en Esparia, Madrid: Instituto de Estudios Económicos.

Weir, M. and T. Skocpol (1985): 'State Structures and the Possibilities for "Keynesian" Responses to the Great Depression in Sweden, Britain, and the United States', in P. Evans, D. Rueschemeyer and T. Skocpol (eds.), Bringing the State Back In, Cambridge: Cambridge University Press, pp.107-63. 